\title{
Effects of pH on human bone marrow stromal cells in vitro: Implications for tissue engineering of bone
}

\author{
David H. Kohn, ${ }^{1,2}$ Mojgan Sarmadi, ${ }^{3}$ Joseph I. Helman, ${ }^{4}$ Paul H. Krebsbach ${ }^{3}$ \\ ${ }^{1}$ Department of Biologic and Materials Sciences, School of Dentistry, The University of Michigan, \\ Ann Arbor, Michigan 48109-1078 \\ ${ }^{2}$ Department of Biomedical Engineering, College of Engineering, The University of Michigan, \\ Ann Arbor, Michigan 48109-2125 \\ ${ }^{3}$ Department of Oral Medicine, Pathology, and Oncology, School of Dentistry, The University of Michigan, \\ Ann Arbor, Michigan 48109-1078 \\ ${ }^{4}$ Department of Oral and Maxillofacial Surgery, School of Dentistry, The University of Michigan, \\ Ann Arbor, Michigan 48109-1078
}

Received 7 September 2000; revised 14 August 2001; accepted 16 August 2001

\begin{abstract}
The objective of this study was to address the hypothesis that changes in extracellular $\mathrm{pH}$ alter collagen gene expression, collagen synthesis, and alkaline phosphatase activity in bone marrow stromal cells (BMSCs). Potential effects of $\mathrm{pH}$ on cell function are of particular importance for tissue engineering because considerable effort is being placed on engineering biodegradable polymers that may generate a local acidic microenvironment on degradation. Human and murine single-cell marrow suspensions were plated at a density of $2 \times 10^{4}$ cells $/ \mathrm{cm}^{2}$. After 7 days in culture, the $\mathrm{pH}$ of the culture medium was adjusted to one of six ranges: $\geq 7.8,7.5 .-7.7,7.2-7.4,6.9-7.1,6.6-6.8$, or $\leq 6.5$. After $48 \mathrm{~h}$ of exposure to an altered $\mathrm{pH}$, alkaline phosphatase activity and collagen synthesis decreased significantly with decreasing $\mathrm{pH}$. This decrease was two-to threefold as
\end{abstract}

$\mathrm{pH}$ decreased from 7.5 to 6.6. In contrast, $\alpha 1(\mathrm{I})$ procollagen mRNA levels increased two- to threefold as $\mathrm{pH}$ was decreased. The trend in osteocalcin mRNA expression was opposite to that of collagen. Small shifts in extracellular $\mathrm{pH}$ led to significant changes in the ability of BMSCs to express markers of the osteoblast phenotype. These $\mathrm{pH}$ effects potentially relate to the microenvironment supplied by a tissue-engineering scaffold and suggest that degrading polymer scaffolds may influence the biologic activity of the cells in the immediate environment. (c) 2002 John Wiley \& Sons, Inc. J Biomed Mater Res 60: 292-299, 2002; DOI 10.1002/ jbm.10050

Key words: $\mathrm{pH}$; bone marrow stromal cells; tissue engineering; polymers; collagen

\section{INTRODUCTION}

When transplanted in scaffolds that support cell adhesion and differentiation, bone marrow stromal cells (BMSCs) are capable of bone formation ${ }^{1-4}$ and can promote the repair or regeneration of osseous defects. $^{5-8}$ Results from in vitro, ectopic, and orthotopic

Correspondence to: Paul H. Krebsbach; e-mail: paulk@ umich.edu or David H. Kohn; e-mail: dhkohn@umich.edu

Contract grant sponsor: Claude Pepper Older Americans Independence Center of the University of Michigan (to P. H. K.)

Contract grant sponsor: National Institutes of Health; contract grant numbers: DE 013835 (to P. H. K.), DE 13380 (to D. H. K.), Independent Scientist Award DE00426 (to P. H. K., sponsored by the National Institute of Dental and Craniofacial Research)

(c) 2002 John Wiley \& Sons, Inc. models, however, show variability in the extent of bone formation and the ability of the new bone to support hematopoiesis. ${ }^{4,9}$ This variability implies that the nature of the microenvironment that cells are exposed to, including the transplantation scaffold, is a critical parameter, especially if human cells are used. . $^{3,10}$

Biodegradable co-polymers of lactic and glycolic acid (PLGA) have been shown to support osteoblast attachment, growth, and function in vitro and in vivo. ${ }^{11-13}$ These co-polymers hydrolytically degrade into products that are readily incorporated into metabolic pathways and are eventually excreted as $\mathrm{CO}_{2}$ and $\mathrm{H}_{2} \mathrm{O} .{ }^{14}$ Therefore, polylactide-co-glycolide copolymers have generally been deemed biocompatible. Nonetheless, use of degradable scaffolds to support cell proliferation and extracellular matrix synthesis implies a transient microenvironment that may influence cell behavior. Moreover, there are incidences of foreign body reactions and bone resorption after im- 
plantation of PLGA fracture fixation devices. ${ }^{15-17}$ It has been theorized that this inflammatory response is associated with the kinetics of polymer degradation and the local capacity of tissues to clear acidic polymeric byproducts. ${ }^{17,18}$ Based on these inflammatory reactions, questions about the biologic responses to acidic degradation products have been raised. ${ }^{19,20}$

Growth and development of a variety of cells, including osteoblasts, are linked to regulation of $\mathrm{pH}$ and acidity of the extracellular microenvironment. ${ }^{21-24}$ The processes of mineralization and repair of skeletal tissues are influenced by the ionic and molecular composition of the extracellular fluids, and it is well known that Ca-P salts are precipitated in a $\mathrm{pH}-$ dependent manner. ${ }^{23,25,26}$ Therefore, it has been suggested that mineralization and bone repair are tissue $\mathrm{pH}$ dependent. ${ }^{23}$ On a cellular level, even modest reductions in extracellular $\mathrm{pH}$ have an effect on osteoblast function in vitro. ${ }^{27,28}$ Cellular mechanisms involved in bone formation and resorption may therefore be responsive to the acid-base balance. ${ }^{28}$ Further knowledge of how $\mathrm{pH}$ affects bone metabolism stems from studies that show that during metabolic acidosis the activity of osteoblasts declines, whereas during metabolic alkalosis osteoblast activity increases. ${ }^{22,29-33}$ Likewise, the $\mathrm{pH}$ in the immediate microenvironment of osteoblasts as well as the intracellular spaces of differentiating bone varies with progressive stages of osteogenesis and may be linked to the regulation of gene expression. ${ }^{27,28,31}$

In light of the physiological relevance of a reduced $\mathrm{pH}$ and the potential relationship to biomaterial-cell interactions, the objective of this study was to address the hypothesis that changes in extracellular $\mathrm{pH}$, such as could be expected within the microenvironment of a tissue engineering scaffold, modulate the expression of genes associated with an osteoblast phenotype in BMSCs. We show that small shifts in extracellular $\mathrm{pH}$ lead to significant changes in the ability of BMSCs to express markers of the osteoblast phenotype. These $\mathrm{pH}$ effects potentially relate to the microenvironment that bone marrow stromal cells would likely be exposed to, at least transiently, if transplanted within degradable polymers.

\section{MATERIALS AND METHODS}

\section{Preparation of BMSC cultures}

Human bone marrow was collected from the long bones of patients undergoing reconstructive surgery. All human samples were collected after informed consent in accordance with appropriate University of Michigan Internal Review Board policy. The bone marrow samples were placed in icecold $\alpha$-modified minimum essential medium ( $\alpha$ MEM; Life
Technologies, Grand Island, NY) with $100 \mathrm{U} / \mathrm{mL}$ sodium heparin (Fisher Scientific, Fair Lawn, NJ), were centrifuged at $100 \mathrm{~g}$ for $10 \mathrm{~min}$, and the cell pellet was resuspended in fresh $\alpha$ MEM. All preparations were pipetted repeatedly to break up cell aggregates. Subsequently, marrow cell suspensions were passed consecutively through 16.5- and 20.5gauge needles before culture.

Single-cell marrow suspensions were plated at a density of $5 \times 10^{6}-5 \times 10^{7}$ nucleated cells per flask. Cells were then cultured at $37^{\circ} \mathrm{C}, 100 \%$ humidity, and $5 \% \mathrm{CO}_{2}$ in flasks containing $30 \mathrm{~mL}$ of differentiating medium ( $\alpha$ MEM, 10\% fetal bovine serum, ascorbic acid, dexamethasone, $100 \mathrm{U} / \mathrm{mL}$ penicillin, $100 \mathrm{mg} / \mathrm{mL}$ streptomycin sulfate, and $1 \mu \mathrm{g} / \mathrm{mL}$ amphotericin). Culture medium was replaced on days 7 and 14. The resulting adherent cells were harvested as follows: cells were washed twice with Hank's balanced salt solution (HBSS), treated with two consecutive applications of trypsin-ethylenediaminetetraacetic acid (EDTA) for 5-10 min each at $37^{\circ} \mathrm{C}$, and washed with medium containing serum.

Mouse bone marrow (Balb/c/C57Bl/6) was harvested from the femoral, tibial, and humeral medullary cavities flushed with $\alpha$-MEM. The entire marrow content of six bones (two each of femur, tibia, and humerus) was plated into $75-\mathrm{cm}^{2}$ culture flasks and was cultured under conditions identical to the human BMSCs. We tested three different cell preparations of murine BMSCs and cells from two different human donors. All experiments were performed at least twice for each cell preparation.

\section{pH modification of culture medium}

The $\mathrm{pH}$ of the culture medium was adjusted to one of six ranges: $\geq 7.8,7.5-7.7,7.2-7.4,6.9-7.1,6.6-6.8$, or $\leq 6.5$ by titrating with an appropriate volume of either $1.0 \mathrm{~N} \mathrm{HCl}$ or $\mathrm{NaOH}$, based on a buffering calibration curve at $37^{\circ} \mathrm{C}$. Before resuspending the cells, medium was incubated for $24 \mathrm{~h}$ under culture conditions to allow the desired $\mathrm{pH}$ ranges to equilibrate. After incubation, a small adjustment in $\mathrm{pH}$ was occasionally required to create the desired final $\mathrm{pH}$. BMSCs were plated at a density of $2.0 \times 10^{4}$ cells $/ \mathrm{cm}^{2}$. A total of 36 six-well dishes were used, such that six wells per $\mathrm{pH}$ range were used for each assay. In parallel, wells containing only medium buffered to the same $\mathrm{pH}$ ranges were maintained. The $\mathrm{pH}$ was monitored with a $\mathrm{pH}$ meter (model 320, Corning). Readings were made at the time of preparation, after equilibrium, and after aspiration of conditioned medium (24 and $48 \mathrm{~h}$ ). Medium was changed at $24 \mathrm{~h}$.

\section{Collagen assay}

After a total culture period of $48 \mathrm{~h}$, cells were harvested. The following assays were performed on human BMSCs: total DNA content, percent collagen synthesis (PCS), alkaline phosphatase activity (ALP), and mRNA analyses for $\alpha 1$ (I) procollagen and osteocalcin (OCN). mRNA levels for $\alpha 1$ (I) procollagen were also determined for mouse BMSCs. Alkaline phosphatase and collagen synthesis were quanti- 
fied by analyzing cells and medium from each well independently. Cells from wells of similar $\mathrm{pH}$ range were pooled for mRNA analyses. The amount of total collagen produced was determined by radiolabeling all synthesized proteins with ${ }^{3} \mathrm{H}$-proline and selectively digesting the collagenous proteins with collagenase. ${ }^{34,35}$ Cells were pulsed with 4 $\mu \mathrm{Ci} / \mathrm{mL}$ and harvested $6 \mathrm{~h}$ later. Proteins were extracted with $1 M$ acetic acid containing $1 \mathrm{mg} / \mathrm{mL}$ pepsin for $4 \mathrm{~h}$ at $25^{\circ} \mathrm{C}$. Aliquots of the protein extracted solutions $(0.2 \mathrm{~mL})$ were added to $1.5-\mathrm{mL}$ microcentrifuge tubes along with 0.1 $\mathrm{mL} \alpha \mathrm{MEM}$ and $0.2 \mathrm{~mL}$ of $0.02 \mathrm{~N} \mathrm{HCL}$ containing $1.25 \mu \mathrm{mol}$ N-ethylmaleimide, $25 \mu \mathrm{g}$ purified collagenase, and 0.25 $\mu \mathrm{mol} \mathrm{CaCl}{ }_{2}$. The tubes were incubated at $37^{\circ} \mathrm{C}$ for $90 \mathrm{~min}$ while agitating. Adding an equal volume of $10 \%$ trichloroacetic acid (TCA) solution containing $0.5 \%$ tannic acid (TA) stopped the reaction. Tubes were placed on ice for $25 \mathrm{~min}$ and centrifuged at $150 \mathrm{~g}$ for $5 \mathrm{~min}$ at $4^{\circ} \mathrm{C}$. Each supernatant solution was transferred to vials containing $12 \mathrm{~mL}$ of scintillation cocktail. Precipitates were resuspended with $0.5 \mathrm{~mL}$ of $5 \%$ TCA with $0.25 \%$ TA and centrifuged under the same conditions. Each supernatant was added to the corresponding vials, and solutions were counted in a scintillation counter for the presence of radioactive proline. Noncollagenous digestible protein (NCP) and collagenous digestible protein (CDP) were determined. The NCP remaining in the precipitates were resuspended in $1.5 \mathrm{~mL}$ of $5 \%$ TCA $/ 0.25 \%$ TA and counted. The amount of collagen was calculated as follows: \% Collagen synthesized $=[\mathrm{CDP} /(\mathrm{CDP}+5.2 \mathrm{NCP})]$ $\times 100$ and then normalized to total DNA content.

\section{Measurement of alkaline phosphatase activity}

Alkaline phosphatase activity was measured spectroscopically by using standard procedures with pnitrophenylphosphate as the substrate. Cultures were washed in HBSS and cell layers were harvested in $0.2-1 \mathrm{~mL}$ lysis buffer, sonicated for $4 \mathrm{~min}$ on ice, and then subjected to three freeze-thaw cycles. Aliquots of $10 \mu \mathrm{L}$ were incubated with p-nitrophenol phosphate/lysis buffer mix (1:1). The presence of ALP was measured by monitoring light absorbance by the solution at $405 \mathrm{~nm}$. The slope of the absorbance versus time curve was used to calculate ALP activity, which was then normalized to total DNA content. Quantitative data for ALP activity and percent collagen synthesis at each $\mathrm{pH}$ were pooled and analyzed via a one-way ANOVA with an all pairwise multiple comparison using a StudentNewman-Keuls test.

\section{RNA extraction and northern blot analysis}

Total RNA (12 $\mu \mathrm{g})$ was separated on a $0.9 \%$ agarose- $1 M$ formaldehyde gel and transferred by capillary action to nylon membranes (Magna NT; MSI). cDNA probes for collagen $\alpha 1(\mathrm{I})$ and OCN were labeled with $\left[\alpha^{32} \mathrm{P}\right] \mathrm{dATP}$ by a randomprimed oligonucleotide method using T4 polynucleotide kinase (Stratagene, La Jolla, CA) and were hybridized at $54^{\circ} \mathrm{C}$. Unincorporated isotope was removed by centrifugation through G-50 Sephadex spin columns (5 Prime-3 Prime Inc., Boulder, CO). Prehybridization, hybridization, and washing conditions were performed by using standard methods. ${ }^{36}$ Blots were stripped and reprobed with an $\left[\alpha^{2} \mathrm{P}\right] \mathrm{dATP}-$ labeled actin cDNA and $\beta$ emissions from the decaying ${ }^{32} \mathrm{P}$ labeled probe were quantified by scanning membranes on a $\beta$-scan instant imager (Packard Instrument Co., Downers Grove, IL).

\section{RESULTS}

Several experiments were performed to determine the effects of $\mathrm{pH}$ on bone marrow stromal cells in culture and to address the hypothesis that extracellular $\mathrm{pH}$ modulates the ability of BMSCs to express markers of the osteoblast phenotype. Because the extracellular $\mathrm{pH}$ was altered just after the cells reached confluence, our experiments defined the effects of $\mathrm{pH}$ on BMSCs that completed the proliferation stage, but had not yet progressed through the matrix maturation and mineral deposition stages of in vitro differentiation. Shifts in $\mathrm{pH}$ over the course of the 48-h experiments were $\pm 0.1-0.3$ for both experimental and control groups. Therefore, results are presented as functions of $\mathrm{pH}$ ranges.

Although present in a number of other tissues, the expression of ALP is a time-honored marker of osteoblast cell function. In in vitro developmental studies, it appears as one of the earliest markers of cells that acquire the ability to form a mineralized matrix. Therefore, expression of ALP activity was used as one of the osteoblast phenotypic markers in our experiments. ALP activity in human BMSCs was influenced by small shifts in $\mathrm{pH}$. After $48 \mathrm{~h}$ of exposure to an altered $\mathrm{pH}, \mathrm{ALP}$ activity in human BMSCs decreased significantly with decreasing $\mathrm{pH}$ (Fig. 1).

The osteoblast synthesizes a complex extracellular matrix of which type I collagen is the major constituent. Like ALP activity, collagen synthesis also significantly decreased in human BMSCs exposed to a more acidic medium (Fig. 2). This decrease was two- to threefold as $\mathrm{pH}$ decreased from 7.5 to 6.6. In contrast, $\alpha 1$ (I) procollagen mRNA levels increased as $\mathrm{pH}$ was decreased in both human (Fig. 3) and murine BMSCs (Fig. 4). When the hybridization signals were normalized to actin mRNA, the collagen mRNA levels increased two- to threefold with decreasing $\mathrm{pH}$ (Figs. 3 and 4). Duplicate experiments with both human and murine cells from different donors yielded similar results (data not shown).

$\mathrm{OCN}$ is a late marker of osteoblast cell function. Although osteocalcin was recently identified in other tissues, it is expressed at high levels in bone-forming cells late in the development of mineralizing cell cul- 


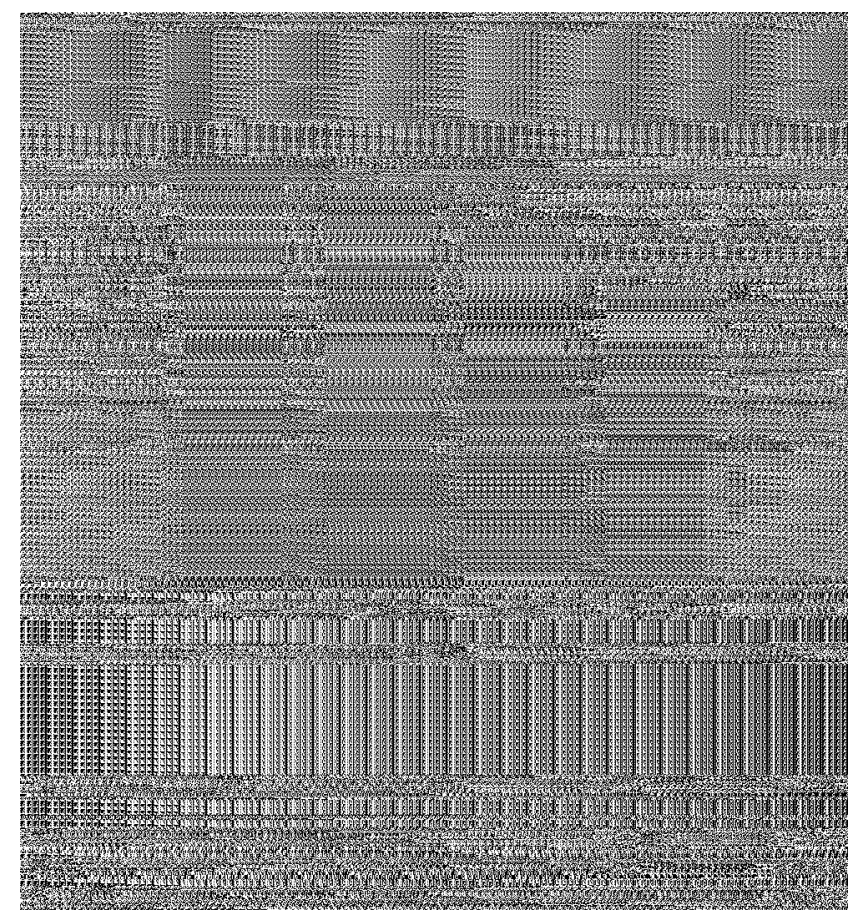

Figure 1. Alkaline phosphatase (ALP) activity normalized to total DNA content in human BMSCs cultured for $48 \mathrm{~h}$ in medium buffered to different $\mathrm{pH}$ ranges. There was a statistically significant decrease in ALP activity with decreasing $\mathrm{pH}$. ns designates a value that is not significantly different, $p>0.05$.

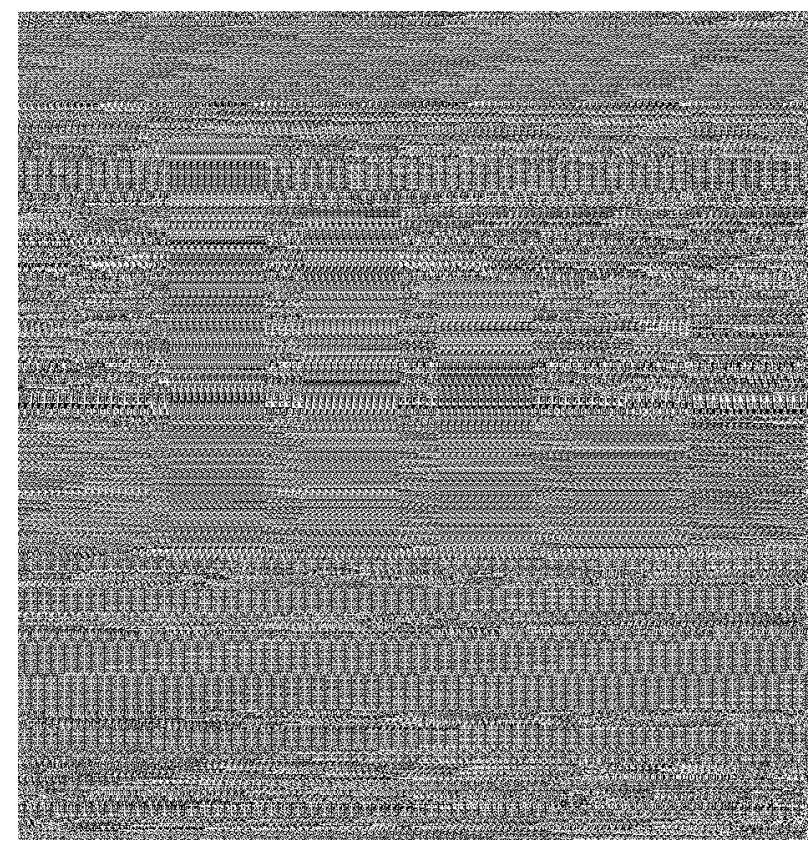

Figure 2. Percent collagen synthesis (PCS) normalized to total DNA content in human BMSCs cultured for $48 \mathrm{~h}$ in medium buffered to different $\mathrm{pH}$ ranges. There was a statistically significant decrease in PCS with decreasing $\mathrm{pH}$. ns designates a value that is not significantly different, $p>0.05$.

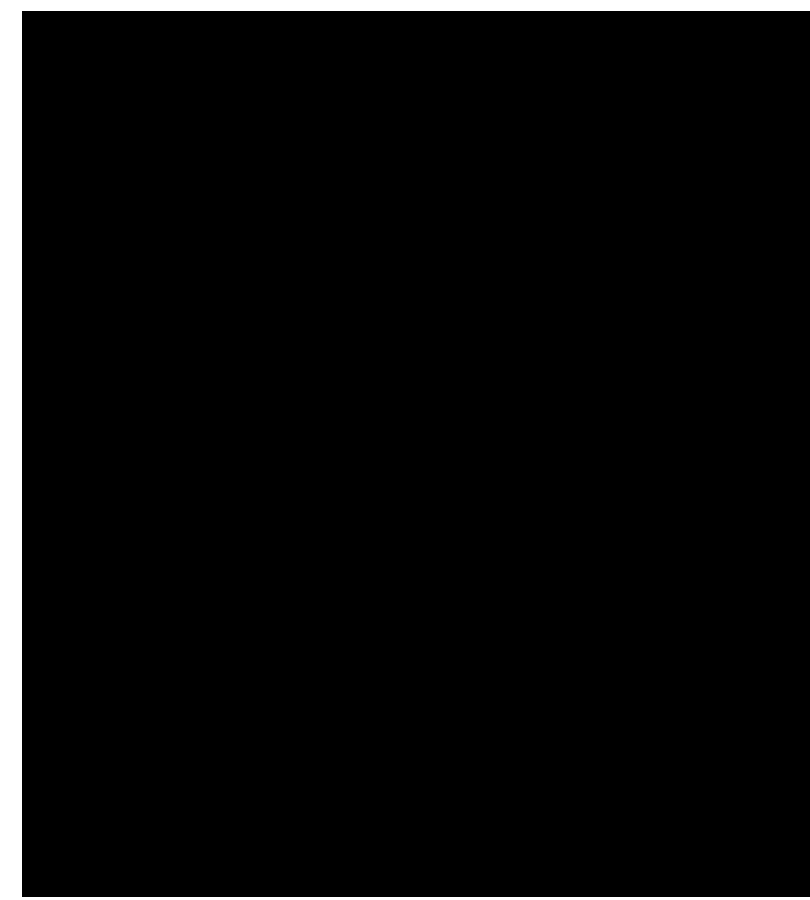

Figure 3. Northern blot analysis of human BMSC $\alpha 1(\mathrm{I})$ procollagen mRNA levels in response to changes in $\mathrm{pH}$. Lane 1, $\mathrm{pH} \geq 7.9$; Lane 2, $\mathrm{pH}=7.7-7.9 ;$ Lane 3, $\mathrm{pH}=7.5-7.7$; Lane 4, $\mathrm{pH}=7.2-7.4$; Lane 5, $\mathrm{pH}=6.9-7.1$; Lane 6, $\mathrm{pH}=$ 6.6-6.8. (A) $\alpha 1$ (I) procollagen mRNA, (B) ethidium bromide staining of nucleic acids, and (C) actin mRNA. The hybridization signals of each gene were quantified by measuring the radioactive decay of ${ }^{32} \mathrm{P}$-labeled probes and are represented by the ratio of $\alpha(\mathrm{I})$ procollagen mRNA to actin mRNA levels (Col1A1/Actin).

tures. $^{37}$ To observe osteocalcin expression in BMSCs, autoradiographs needed to be exposed for 7 days and therefore led to a higher than normal background. Despite the high background, osteocalcin mRNA levels could be detected. The trend in OCN mRNA expression in human BMSCs (Fig. 5) was opposite to that of procollagen. Osteocalcin was expressed at low levels at superphysiological $\mathrm{pH}$ levels and declined rapidly to undetectable levels below physiological $\mathrm{pH}$.

\section{DISCUSSION}

Proliferation and differentiation of osteoblasts and the formation of mineralized tissue are linked to $\mathrm{pH}$ regulation. ${ }^{22,23,32}$ Likewise, the osteogenic capacity of BMSCs also varies depending on the culture environment. ${ }^{10,38-40}$ On the basis of the results of this study, it is clear that small shifts in extracellular $\mathrm{pH}$ lead to significant changes in the ability of BMSCs to express markers of the osteoblast phenotype. The trends in ALP and collagen synthesis (Figs. 1 and 2) are consistent with previously reported data from osteoblastlike cell lines ${ }^{28}$ and cultured human osteoblasts. ${ }^{27}$ However, in this study the effects of extracellular $\mathrm{pH}$ 


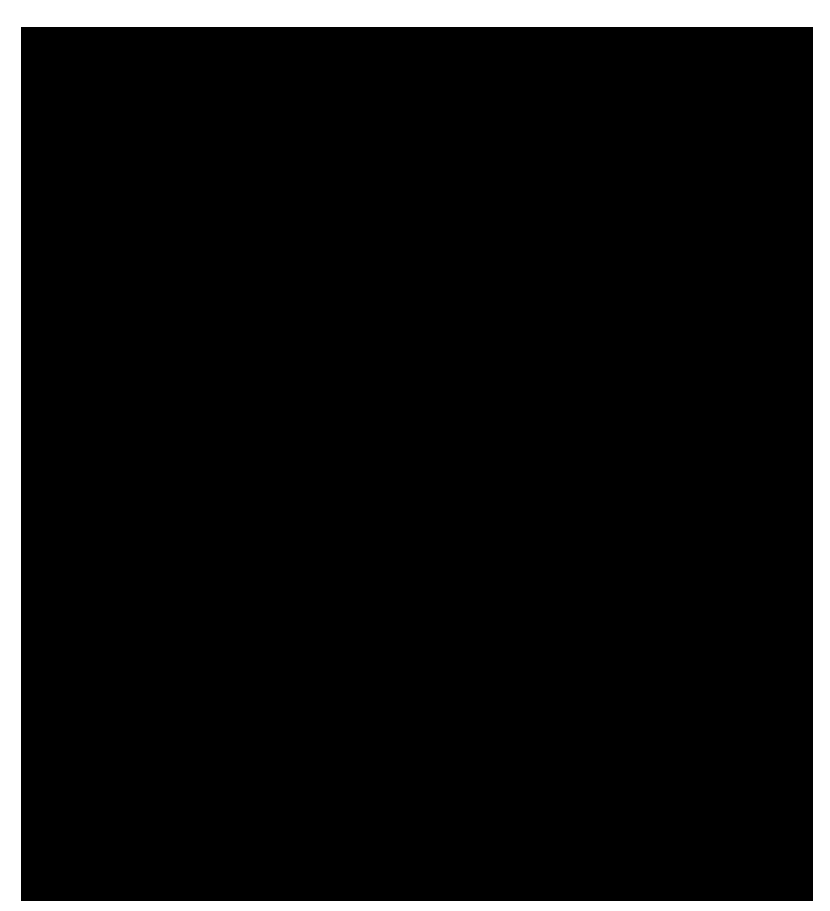

Figure 4. Northern blot analysis of mouse BMSC $\alpha 1$ (I) procollagen mRNA levels in response to changes in $\mathrm{pH}$. Lane 1, $\mathrm{pH} \geq 7.9$; Lane 2, $\mathrm{pH}=7.7-7.9$; Lane 3, $\mathrm{pH}=7.5-7.7$; Lane $4, \mathrm{pH}=7.2-7.4 ;$ Lane 5, $\mathrm{pH}=6.9-7.1$; Lane 6, $\mathrm{pH}=6.6-6.8$. (A) $\alpha 1$ (I) procollagen mRNA, (B) ethidium bromide staining of nucleic acids, and (C) actin mRNA. The hybridization signals of each gene were quantified by measuring the radioactive decay of ${ }^{32} \mathrm{P}$-labeled probes and are represented by the ratio of $\alpha 1$ (I) procollagen mRNA to actin mRNA levels (Col1A1/Actin).

on cell function and gene expression were performed on BMSCs, a population of cells that unlike cell lines may serve as an abundant source of osteoprogenitor cells for skeletal tissue regeneration in humans.

The inverse trends between collagen synthesis (Fig. 2 ) and procollagen mRNA levels (Figs. 3 and 4) were not anticipated. Collagen content has routinely been shown to decrease with decreasing extracellular $\mathrm{pH}$ in vitro, a result that has been attributed to lower $\alpha 1$ (I) procollagen gene expression. ${ }^{27,28}$ The trend in osteocalcin expression in human BMSCs with changing $\mathrm{pH}$ (Fig. 5) was opposite to that of $\alpha 1(\mathrm{I})$ procollagen expression. Osteocalcin mRNA was expressed at low levels at high $\mathrm{pH}$ and declined to undetectable levels below physiological $\mathrm{pH}$. In this manner, OCN expression followed type I collagen synthesis and not $\alpha 1$ (I) procollagen gene expression. The low level of OCN expression was anticipated because of the relatively short-term culture period used and the fact that cells had not yet reached the mineral deposition stage. ${ }^{41}$

The experiments performed were short-term in vitro studies, as were many of the material degradation/ $\mathrm{pH}$ and cell culture $/ \mathrm{pH}$ studies that motivated our hypothesis. ${ }^{20,27,28,31}$ There is still debate about the role of the body itself in buffering of degradation products in an in vivo microenvironment. By analogy to wound healing, degradation-mediated acidity could be important in vivo. During wound healing, relatively acidic conditions prevail. ${ }^{42,43}$ Low blood flow and poor oxygenation can result in a decreased ability to nourish bone cells and remove metabolic waste products such as lactic acid. ${ }^{27,44}$ Conversely, patients with respiratory alkalosis have an increased rate of fracture healing. ${ }^{45}$ Therefore, the collective literature indicates that biomineralization and skeletal regeneration are influenced by the ionic composition and $\mathrm{pH}$ of the extracellular microenvironment ${ }^{23,25,26}$ and that the magnitude of the $\mathrm{pH}$ drop in a wound healing microenvironment is equivalent to the range of $\mathrm{pH}$ that reduces osteoblast function, as determined in the current experiments and elsewhere. ${ }^{27,28}$

Having demonstrated that small $\mathrm{pH}$ shifts significantly affect BMSC function and that these shifts are physiologically relevant, it is important to note that many acid-base effects on the bone microenvironment also potentially relate to the microenvironment supplied by an engineered scaffold. This is of particular importance for tissue engineering because considerable effort is being placed on producing biodegradable polymer scaffolds for localized skeletal regeneration. The magnitude of the $\mathrm{pH}$ changes studied here reflect $\mathrm{pH}$ shifts that bone cells would likely be exposed to, for at least a short period of time, if seeded on a degradable polymer. ${ }^{43,46,47}$ The physiological scenarios in which declining $\mathrm{pH}$ leads to acid buildup and reduction in osteoblast function may be analogous to the cellular response to resorbable polymer degradation products. Hydrolysis of poly( $\alpha$-hydroxyacid)-based polymers is acid catalyzed and accelerates once

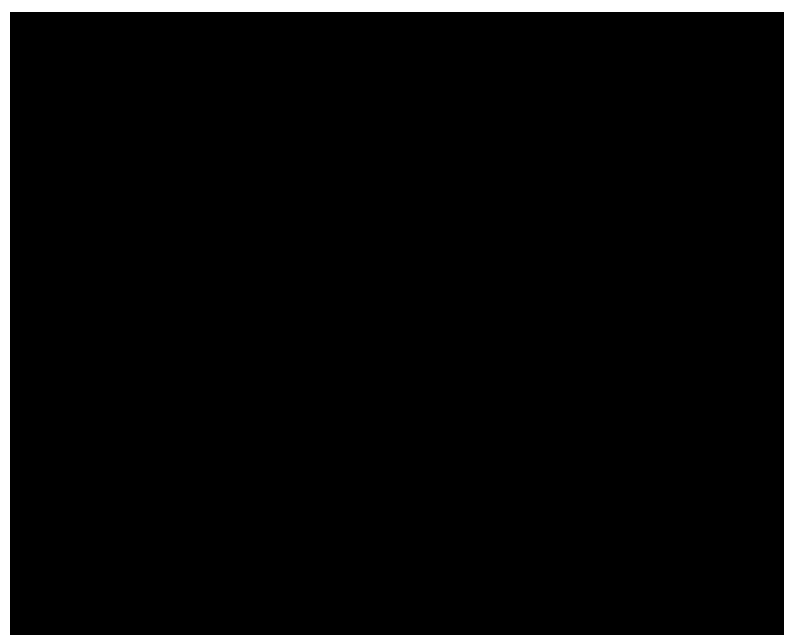

Figure 5. Northern blot analysis of human BMSC osteocalcin (OCN) mRNA as a function of medium $\mathrm{pH}$. Lane 1, $\mathrm{pH}$ $\geq 7.9$; Lane 2, $\mathrm{pH}=7.7-7.9$; Lane 3, $\mathrm{pH}=7.5-7.7$; Lane 4, $\mathrm{pH}$ = 7.2-7.4; Lane 5, pH = 6.9-7.1; Lane 6, $\mathrm{pH}=6.6-6.8$. OCN $\mathrm{mRNA}$ levels decrease with decreasing $\mathrm{pH}$, a trend opposite to that of collagen mRNA (Figs. 3 and 4 ). 
started. The $\mathrm{pH}$ in the eroding zone of degrading polymers has been measured to be as low a 2.06.0. ${ }^{46-49}$ Changes in the local microenvironment produced by acidic PLGA degradation products may, therefore, inhibit bone metabolism and impair healing, at least for more dense forms of these materials where diffusion may be restricted by a fluidconstraining microenvironment. ${ }^{46}$ To compensate for these potentially adverse biological effects, investigators have begun modifying these co-polymers to neutralize the acidic degradation products. Buffering the microenvironment may be achieved by incorporating basic salts within polymers ${ }^{48}$ or by generating composite polymer scaffolds containing a carbonated apatite mineral surface. ${ }^{50}$

Long-term organ culturing on PLGA showed a progressive acidification of the culture medium, reaching a level as low as 4.1, leading to decreased glycolysis, collagen synthesis, and mineral content. ${ }^{47}$ Other work on osseous tissue engineering has shown that it is necessary to precondition the surfaces of glasses because ionic leaching leads to a profound and rapid change in cell function and activity. ${ }^{51}$ These latter two studies, along with the $\mathrm{pH}$-dependence of biomaterial function, ${ }^{25,26}$ indicate that even in the absence of $\mathrm{pH}$ effects in vivo, the microenvironment of in vitro cell seeding can be impacted, thus influencing tissue engineering efficiency. Finally, it should be recognized that $\mathrm{pH}-$ dependent effects in vitro are still important, especially if tissue engineering applications move toward use of osteoprogenitor or stem cells. Therefore, the results of these studies could impact the ex vivo expansion of cells for tissue engineering applications.

The specific cellular and molecular mechanisms responsible for the observations made in this study are not yet fully understood. It is not known whether the $\mathrm{pH}$ effects represent an effect on BMSC differentiation or proliferation of a specific subpopulation of cells, or what second messengers may be involved. The inverse trends between $\alpha 1$ (I) procollagen gene expression and collagen synthesis suggest an uncoupling of transcription and translation. A similar finding of uncoupling of collagen transcription and translation has been reported for other insults to cultured osteoblasts, such as addition of tumor necrosis factor- $\alpha .^{52}$

A potential mechanism for the observed uncoupling of collagen transcription and translation involves the role of heat shock proteins in collagen biosynthesis. Lower $\mathrm{pH}$ weakens the association of heat shock protein-47 (HSP47), a collagen chaperone, with the nascent procollagen polypeptide. Close association of HSP47 is essential for proper folding of procollagen molecules until export to the Golgi apparatus. ${ }^{53}$ Procollagen propeptides separated from HSP47 in an acidic environment rapidly degrade, leading to a net decline in collagen synthesis. The association between HSP47 and procollagen propeptide is $\mathrm{pH}$ dependent and is disrupted below $\mathrm{pH}=6.5 .^{54-56}$

In addition to increasing the $\mathrm{H}^{+}$concentration, the addition of $\mathrm{HCl}$ to the culture medium results in an increased $\mathrm{Cl}^{-}$concentration in the extracellular medium. The $\mathrm{Cl}^{-}$gradient stimulates the $\mathrm{HCO}_{3}{ }^{-} / \mathrm{Cl}^{-}$exchanger, which in turn may lower intracellular $\mathrm{pH}$ $\left(\mathrm{pH}_{\mathrm{i}}\right) .^{57-59}$ The $\mathrm{HCO}_{3}{ }^{-} / \mathrm{Cl}^{-}$pump is known to be involved in the regulatory pathways of osteoblasts ${ }^{22}$ and has also been shown to reduce intracellular cAMP levels. ${ }^{21}$ A reduction in $\mathrm{pH}_{\mathrm{i}}$ also changes mitochondrial activity (higher ATP/lower cAMP) and causes release of $\mathrm{Ca}^{2+}$ from mitochondria. ${ }^{60,61}$ Increased levels of intracellular $\mathrm{Ca}^{2+}$ affect signal transduction pathways, ${ }^{62,63}$ and, depending on the pathways active in a specific cell population or developmental stage, a variety of physiological responses may be observed.

Although the use of a heterogeneous cell population makes discerning mechanisms of action difficult, this pluripotent cell population reflects the in vivo reality for many tissue engineering applications. The $\mathrm{pH}$ effects on BMSCs observed in this study potentially relate to the microenvironment supplied by a tissueengineering scaffold and suggest that degrading polymer scaffolds may influence the biologic activity of the cells in the immediate environment.

\section{References}

1. Friedenstein A, Kuralesova AI. Osteogenic precursor cells of bone marrow in radiation chimeras. Transplantation 1971;12: 99-108.

2. Goshima J, Goldberg VM, Caplan AI. The osteogenic potential of culture-expanded rat marrow mesenchymal cells assayed in vivo in calcium phosphate ceramic blocks. Clin Orthop 1991; 262:298-311.

3. Krebsbach PH, Kuznetsov SA, Satomura K, Emmons RV, Rowe DW, Robey PG. Bone formation in vivo: comparison of osteogenesis by transplanted mouse and human marrow stromal fibroblasts. Transplantation 1997;63:1059-1069.

4. Kuznetsov SA, Krebsbach PH, Satomura K, Kerr J, Riminucci M, Benayahu D, Gehron Robey P. Single-colony derived strains of human stromal fibroblasts form bone after transplantation in vivo. J Bone Miner Res 1997;12:1335-1347.

5. Kon E, Muraglia A, Corsi A, Bianco P, Marcacci M, Martin I, Boyde A, Ruspantini I, Chistolini P, Rocca M, Giardino R, Cancedda R, Quarto R. Autologous bone marrow stromal cells loaded onto porous hydroxyapatite ceramic accelerate bone repair in critical-size defects of sheep long bones. J Biomed Mater Res 2000;49:328-337.

6. Richards M, Huibregtse BA, Caplan AI, Goulet JA, Goldstein SA. Marrow-derived progenitor cell injections enhance new bone formation during distraction. J Orthop Res 1999;17:900908.

7. Bruder SP, Kraus KH, Goldberg VM, Kadiyala S. The effect of 
implants loaded with autologous mesenchymal stem cells on the healing of canine segmental bone defects. J Bone Joint Surg Am 1998;80:985-996.

8. Krebsbach PH, Mankani MH, Satomura K, Kuznetsov SA, Robey PG. Repair of craniotomy defects using bone marrow stromal cells. Transplantation 1998;66:1272-1278.

9. Solchaga LA, Johnstone B, Yoo JU, Goldberg VM, Caplan AI. High variability in rabbit bone marrow-derived mesenchymal cell preparations. Cell Transplant 1999;8:511-519.

10. Martin I, Muraglia A, Campanile G, Cancedda R, Quarto R. Fibroblast growth factor-2 supports ex vivo expansion and maintenance of osteogenic precursors from human bone marrow. Endocrinology 1997;138:4456-4462.

11. Ishaug SL, Crane GM, Miller MJ, Yasko AW, Yaszemski MJ, Mikos AG. Bone formation by three-dimensional stromal osteoblast culture in biodegradable polymer scaffolds. J Biomed Mater Res 1997;36:17-28.

12. Ishaug-Riley SL, Crane GM, Gurlek A, Miller MJ, Yasko AW, Yaszemski MJ, Mikos AG. Ectopic bone formation by marrow stromal osteoblast transplantation using poly(DL-lactic-coglycolic acid) foams implanted into the rat mesentery. J Biomed Mater Res 1997;36:1-8.

13. Vacanti CA, Vacanti JP. Bone and cartilage reconstruction with tissue engineering approaches. Otolaryngol Clin North Am 1994;27:263-276.

14. Williams DF, Mort E. Enzyme-accelerated hydrolysis of polyglycolic acid. J Bioeng 1977;1:231-238.

15. Bergsma EJ, Rozema FR, Bos RR, de Bruijn WC. Foreign body reactions to resorbable poly(L-lactide) bone plates and screws used for the fixation of unstable zygomatic fractures. J Oral Maxillofac Surg 1993;51:666-670.

16. Bostman O, Hirvensalo E, Makinen J, Rokkanen P. Foreignbody reactions to fracture fixation implants of biodegradable synthetic polymers. J Bone Joint Surg [Br] 1990;72:592-596.

17. Therin M, Christel P, Li S, Garreau H, Vert M. In vivo degradation of massive poly(alpha-hydroxy acids): validation of in vitro findings. Biomaterials 1992;13:594-600.

18. Vert M, Mauduit J, Li S. Biodegradation of PLA/GA polymers: increasing complexity. Biomaterials 1994;15:1209-1213.

19. Suganuma J, Alexander H. Biological response of intramedullary bone to poly-l-lactic acid. J Appl Biomat 1993;4:13-17.

20. Taylor MS, Daniels AU, Andriano KP, Heller J. Six bioabsorbable polymers: in vitro acute toxicity of accumulated degradation products. J Appl Biomat 1994;5:151-157.

21. Green J. Cytosolic pH regulation in osteoblasts. Miner Electrolyte Metab 1994;20:16-30.

22. Arnett TR, Dempster DW. Protons and osteoclasts. J Bone Miner Res 1990;5:1099-1103.

23. Chakkalakal DA, Mashoof AA, Novak J, Strates BS, McGuire $\mathrm{MH}$. Mineralization and $\mathrm{pH}$ relationships in healing skeletal defects grafted with demineralized bone matrix. J Biomed Mater Res 1994;28:1439-1443.

24. Wu LN, Wuthier MG, Genge BR, Wuthier RE. In situ levels of intracellular $\mathrm{Ca} 2+$ and $\mathrm{pH}$ in avian growth plate cartilage. Clin Orthop 1997;335:310-324.

25. Johnson MSA, Nancollas GA. The role of brushite and octacalcium phosphate in apatite formation. Crit Rev Oral Biolo Med 1992;1992:61-82.

26. Posner AS. The mineral of bone. Clin Orthop 1985;200:87-99.

27. Kaysinger KK, Ramp WK. Extracellular $\mathrm{pH}$ modulates the activity of cultured human osteoblasts. J Cell Biochem 1998;68: 83-89.

28. Ramp WK, Lenz LG, Kaysinger KK. Medium pH modulates matrix, mineral, and energy metabolism in cultured chick bones and osteoblast-like cells. Bone Miner 1994;24:59-73.

29. Bushinsky DA, Goldring JM, Coe FL. Cellular contribution to $\mathrm{pH}$-mediated calcium flux in neonatal mouse calvariae. Am J Physiol 1985;248:F785-F789.
30. Bushinsky DA. Metabolic alkalosis decreases bone calcium efflux by suppressing osteoclasts and stimulating osteoblasts. Am J Physiol 1996;271:F216-F222.

31. Frick KK, Jiang L, Bushinsky DA. Acute metabolic acidosis inhibits the induction of osteoblastic egr- 1 and type 1 collagen. Am J Physiol 1997;272:C1450-C1456.

32. Frick KK, Bushinsky DA. Chronic metabolic acidosis reversibly inhibits extracellular matrix gene expression in mouse osteoblasts. Am J Physiol 1998;275:F840-F847.

33. Krieger NS, Sessler NE, Bushinsky DA. Acidosis inhibits osteoblastic and stimulates osteoclastic activity in vitro. Am J Physiol 1992; 262:F442-F448.

34. Kream BE, Rowe D, Smith MD, Maher V, Majeska R. Hormonal regulation of collagen synthesis in a clonal rat osteosarcoma cell line. Endocrinology 1986;119:1922-1928.

35. Peterkofsky B, Diegelmann R. Use of a mixture of proteinasefree collagenases for the specific assay of radioactive collagen in the presence of other proteins. Biochemistry 1971;10:988994.

36. Sambrook J, Fritsch EF, Maniatis T. Molecular cloning: a laboratory manual. 2nd ed. Cold Spring Harbor, NY: Cold Spring Harbor Laboratory Press; 1989.

37. Owen TA, Aronow M, Shalhoub V, Barone LM, Wilming L, Tassinari M S, Kennedy MB, Pockwinse S, Lian JB, Stein G S. Progressive development of the rat osteoblast phenotype in vitro: reciprocal relationships in expression of genes associated with osteoblast proliferation and differentiation during formation of the bone extracellular matrix. J Cell Physiol 1990;143: 420-430.

38. Bruder SP, Jaiswal N, Haynesworth SE. Growth kinetics, selfrenewal, and the osteogenic potential of purified human mesenchymal stem cells during extensive subcultivation and following cryopreservation. J Cell Biochem 1997;64:278-294.

39. Krebsbach PH, Kuznetsov SA, Bianco P, Gehron Robey P. Bone marrow stromal cells: characterization and clinical application. Crit Rev Oral Bio Med 1999;10:165-181.

40. Kuznetsov SA, Friedenstein AJ, Gehron Robey P. Factors required for bone marrow stromal fibroblast colony formation in vitro. Br J Haematol 1997;97:561-570.

41. Stein GS, Lian JB, Owen TA. Bone cell differentiation: a functionally coupled relationship between expression of cellgrowth- and tissue-specific genes. Curr Opin Cell Biol 1990;2: 1018-1027.

42. Newman RJ, Duthie RB, Francis MJ. Nuclear magnetic resonance studies of fracture repair. Clin Orthop 1985;198:297-303.

43. Winet $\mathrm{H}$, Martin $\mathrm{C}$. In vivo $\mathrm{pH}$ changes near an eroding polyactide-polyglycolide device in the rabbit bone chamber. Trans Soc Biomat 1998;24:378.

44. Whiteside LA, Simmons DJ, Lesker PA. Comparison of regional bone blood flow in areas with differing osteoblastic activity in the rabbit tibia. Clin Orthop 1977;124:267-270.

45. Newman RJ, Stone MH, Mukherjee SK. Accelerated fracture union in association with severe head injury. Injury 1987;18: 241-246.

46. Athanasiou KA, Schmitz JP, Agrawal CM. The effects of porosity on in vitro degradation of polylactic-polyglycolic acid implants used in repair of articular cartilage. Tissue Eng 1998; 4:53-63.

47. Tokita F, Ramp WK, Nicholson NC, Vook NC, Raulin LA, Jacob E. Poly-(dl-lactide-co-glycollide) is toxic to cultured chick tibiae. Trans Soc Biomat 1998;24:465.

48. Agrawal CM, Athanasiou KA. Technique to control $\mathrm{pH}$ in vicinity of biodegrading PLA-PGA implants. J Biomed Mater Res 1997;38:105-114.

49. Mader K, Nitschke S, Stosser R, Borchert HH, Domb A. Nondestructive and localized assessment of acidic microenvironments inside biodegradaable polyanhydrides by spectral spa- 
tial electron paramagnetic resonance imaging. Polymer 1997; 38:4785-4794.

50. Murphy WL, Kohn DH, Mooney DJ. Growth of continuous bonelike mineral within porous poly(lactide-co-glycolide) scaffolds in vitro. J Biomed Mater Res 2000;50:50-58.

51. El-Ghannam A, Ducheyne P, Shapiro IM. Porous bioactive glass and hydroxyapatite ceramic affect bone cell function in vitro along different time lines. J Biomed Mater Res 1997;36: 167-180.

52. Centrella M, McCarty TL, Canalis E. Tumor necrosis factor-a inhibits collagen synthesis and alkaline phosphatase activity independently of its effect on deoxyribonucleic acid synthesis in osteoblast-enriched bone cell cultures. Endocrinology 1998; 123:1442-1448.

53. Smith T, Ferreira LR, Hebert C, Norris K, Sauk JJ. Hsp47 and cyclophilin B traverse the endoplasmic reticulum with procollagen into pre-Golgi intermediate vesicles: a role for Hsp47 and cyclophilin B in the export of procollagen from the endoplasmic reticulum. J Biol Chem 1995;270:18323-18328.

54. Nakai A, Hirayoshi K, Saga S, Yamada KM, Nagata K. The transformation-sensitive heat shock protein (hsp47) binds specifically to Fetuin. Biochem Biophys Res Commun 1989;164: 259-264.

55. Nakai A, Satoh M, Hirayoshi K, Nagata K. Involvement of the stress protein HSP47 in procollagen processing in the endoplasmic reticulum. J Cell Biol 1992;117:903-914.

56. Satoh M, Hirayoshi K, Yokota S, Hosokawa N, Nagata K. In- tracellular interaction of collagen-specific stress protein HSP47 with newly synthesized procollagen. J Cell Biol 1996;133:469483.

57. Teti A, Blair HC, Teitelbaum SL, Kahn AJ, Koziol C, Konsek J, Zambonin-Zallone A, Schlesinger PH. Cytoplasmic $\mathrm{pH}$ regulation and chloride/bicarbonate exchange in avian osteoclasts. J Clin Invest 1989;83:227-233.

58. Ganz MB, Boyarsky G, Sterzel RB, Boron WF. Arginine vasopressin enhances $\mathrm{pHi}$ regulation in the presence of HCO3- by stimulating three acid-base transport systems. Nature 1989; 337:648-651.

59. Baltz JM. Intracellular $\mathrm{pH}$ regulation in the early embryo. Bioessays 1993;15:523-530.

60. Blaich G, Krell H, Tafler M, Pfaff E. On the state of calcium ions in isolated rat liver mitochondria. II. Effects of phosphate and $\mathrm{pH}$ on $\mathrm{Ca} 2+-$ induced $\mathrm{Ca} 2+$ release. Hoppe Seylers Z Physiol Chem 1984;365:73-82.

61. Lemasters JJ, Chacon E, Ohata H, Harper IS, Nieminen AL, Tesfai SA, Herman B. Measurement of electrical potential, pH, and free calcium ion concentration in mitochondria of living cells by laser scanning confocal microscopy. Methods Enzymol 1995;260:428-444.

62. Duchen MR. Mitochondria and calcium: from cell signalling to cell death. J Physiol 2000;529:57-68.

63. Ichas F, Jouaville LS, Mazat JP. Mitochondria are excitable organelles capable of generating and conveying electrical and calcium signals. Cell 1997;89:1145-1153. 